\title{
Stjålne kort
}

\author{
Essayistikken som kritik af den geopolitiske fantasi
}

\author{
STEFAN JONSSON
}

Med trehundrede soldater og nogle heste har Hernán Cortés, ledsaget af indianere fra Tlaxcala, begivet sig fra Vera Cruz ved kysten til Mexicos indre højland. Spanierne er udmattede og Cortés har brændt sine skibe for at hindre et tilbagetog. Den 8 . november I5I9 går de over Texcoco-søen ad de lange, brede træbroer som fører til aztekernes hovedstad. Med sine 200.000 indbyggere er Tenochtitlán større og mere strålende end nogen by $\mathrm{i}$ datidens Europa.

„Da vi gik over broen kom Montezuma os i møde med tohundrede adelsmænd", skriver Cortés i sin rapport til den spanske konge, Karl V. „Og mens jeg talte med Montezuma tog jeg en halskæde af glasperler af og kastede om hans hals.“

Montezuma får sten af glas. Til gengæld får Cortés to halskæder med otte figurer som ligner rejer, hver af dem femten centimeter lang og af massivt guld. Det er erobringens mønster. Men bortset fra den bedrageriske byttehandel præges mødet af parternes gensidige uformån $\mathrm{i}$ at forstå hinanden. Dette beror ikke kun på at deres tungemål er forskellige. Montezuma og Cortés ved knap nok om de skal betragte hinanden som mennesker.

Da soldaten Bernal Diaz del Castillo skal beskrive mødet mellem Cortés og Montezuma slår hans stil knuder på sig selv:

Det syntes os som om vi så de fortryllede slotte, der beskrives i bogen om Amadis, så prægtige var tårnene, templerne og de $i$ vandet opførte stenbygninger. Nogle af soldaterne spurgte til og med om ikke dette syn var en drøm. Man må ikke undre sig over at jeg siger således, for det bør betænkes at jeg ikke ved hvordan jeg skal beskrive det som ingen før har set, ej heller hørt om, ja end ikke drømt om.
Da jeg i begyndelsen af I980'erne studerede i Uppsala og tilbragte dagene $\mathrm{i}$ universitetets bibliotek, skete det engang imellem at jeg efter en rygepause i kantinen gik ind i bibliotekets lille museum for at beundre en bog, som lå opslået i en montre af armeret glas. Denne bog fra 500-tallet indeholder de fire evangelier i gotisk oversættelse og teksten er prentet på purpurfarvet pergament med blæk af rent sølv.

Codex argenteus, Sølvbiblen, skal være en af verdens mest værdifulde bøger. Dengang var jeg en smule stolt over, at biblen var hvor den var - i mit hjemland, ved mit universitet, blandt mine lånebøger. Samtidig vidste jeg, at den egentlig burde ligge et andet sted, måske i Ravenna hvor den skal være forfærdiget i 500-tallet, måske i klostret i Werden hvor den blev opbevaret i mange hundrede år, måske $\mathrm{i}$ det kejserlige bibliotek i Prag som ejede Sølvbiblen, inden den blev bortført af den svenske hær, der plyndrede byen i juli I648. Sølvbiblen var kilde til både henrykkelse og skyldfølelse. Fordi den fandtes i Uppsala fik jeg en smule indsigt i middelalderens bogproduktion, men at den fandtes i Uppsala skyldtes krigsherrers hærgen. Sølvskriften var en legering af kultur og barbari.

Eftersom Sølvbiblen var en tyvekost var det på sin vis logisk, at to maskerede mænd den 5. april 1995 slog det armerede glas i stykker og stjal værket. Hvor mærkeligt det end kan lyde, blev tyveriet foregrebet $\mathrm{i}$ en roman, Göran Tunströms Tyven (I986). Hovedpersonen er en fattig Uppsalastudent som tilegner sig alt der er at vide om Sølvbiblen, men hans forskning har kun det ene mål: at blive alene med 
pragtværket og stuve det ned i sin røversæk. Viljen til at vide er $\mathrm{i}$ hans tilfælde betinget af viljen til at eje, og viljen til at eje avler hans vilje til at stjæle. Sådan fungerer den instrumentelle fornuft, fortæller Tunströms roman. Viden drives af viljen til at beherske tingene i verden. Adorno siger det samme, når han skriver at den videnskabelige indsigt drejer sig om at underordne tingen under begrebet.

Essayformen bæres ifølge Adorno af viljen til at løsrive tingen fra begrebets vold. Heri ligger dets kulturkritiske potentiale. Essayet gør gengæld for begrebets overgreb på samfundets mangfoldighed og genindsætter dermed verden i dens dynamisk og historisk foranderlige naturtilstand. Men videnskabens begrebslighed vokser og dens overgreb øges så hurtigt, at kritikken, hvor effektiv den end måtte være, aldrig kan give alle tyvekoster tilbage. I en verden hvor alle forbrydelser var opklarede ville detektiverne være arbejdsløse. Men essayisten er én gang for alle sådan en detektiv, hans eller hendes udredning er opklaringen af en forbrydelse.

Der gik mange år før jeg fik øjnene op for et andet dokument, som udstilles på samme museum lige bagved Codex argenteus. Det er et slidt pergamentark, bemalet med svage, delvis falmede felter i gråt, grønt og blåt, samt med linjer i lyseblåt og brunt som forestiller henholdsvis kanaler og veje. På arket er der huse, hytter, buske, bjergtoppe, dæmningsværker og en mængde halvnøgne menneskefigurer, som jager, fisker, danser, pløjer, vogter kvæg eller slæber sig afsted med tunge byrder på ryggen, ofte drevet frem af herrer i rustning. På billedet finder man også stednavne og hieroglyfiske tegn.

I nederste højre hjørne er der et titelfelt i brunt. En tredjedel af feltet er revet af og det meste af teksten er ulæselig, men dens begyndelse kan tydes: „Cæsaris omnis Hispaniæ CAROLI. V... ALFONSVS De S... Cr.... VRBEM hanc Temixtitan... quondam offerimus..." Billedet forestiller med andre ord Tenochtitlán, vore dages Mexico City, og tilegnes kejser Karl V af Alonso De Santa Cruz, hvilket bekræftes af at kejserens våben er tegnet over bladets nedre kant, sammen med hans valgsprog „Plus ultra“.

Det er let at datere billedet. I efteråret I555 ramtes Tenochtitlán af voldsomme oversvømmelser, forårsaget af at spanierne ikke vidste hvordan man regulerede vandstanden $\mathrm{i}$ Texcoco, søen $\mathrm{i}$ hvilken aztekerne $i$ begyndelsen af I300-tallet havde bygget deres by af pælebårne huse og flydende haver. Efter oversvømmelserne gav vicekongen Luis de Velasco ordre til, at der skulle bygges en ny dæmning. Arbejdet blev påbegyndt i oktober I555 og afsluttedes i februar 1556. Noget af det tydeligste på billedet er netop den nye dæmning, San Lazaro-volden. Billedet kan således ikke være tegnet før opdæmningen. Men det kan heller ikke være udført efter 1556 , for i dette år abdicerede Karl V og blev erstattet af sin søn, Filip II. Således kan billedet dateres til slutningen af 1555 eller begyndelsen af 1556 .

$\star$

Næsten enhver svensker har hørt om Sølvbiblen. Den betragtes som et nationalklenodie. Hvor mange har hørt tale om Alonso de Santa Cruz og hans Mexico-kort? Det er svært at tænke sig en roman om en helt som stjal kortet. Hvordan skulle man kunne vække læserens interesse for tyveriet af en genstand, som næsten ingen ville savne? Santa Cruz-kortet er ikke engang gjort til genstand for en dækkende teknisk eller videnskabelig analyse. Og alligevel er kortet lige så enestående som Codex argenteus, og langt rigere på information. Det er det eneste bevarede originalkort som både $\mathrm{i}$ helhed og detaljer viser, hvordan Tenochtitlán så ud kort efter spaniernes erobring.

Jeg har ofte grundet over billedet: et næsten glemt kort med næsten ulæsbare tegn, et vidnesbyrd fra afdøde mennesker på et uddødt sprog som skildrer et tyveri, der allerede for længe siden faldt for forældelsesfristen. Kortet fremkalder intellektuel angst og forvirring, en forvirring som tiltager da jeg finder ud af at ingen ved hvordan kortet er havnet $i$ 
Uppsala, og som vokser yderligere da det går op for mig, at hverken kortets angivelige ophavsmand, Alonso de Santa Cruz, eller kortets ejer, kejseren selv, har vidst hvad billedet på kortet egentlig forestillede.

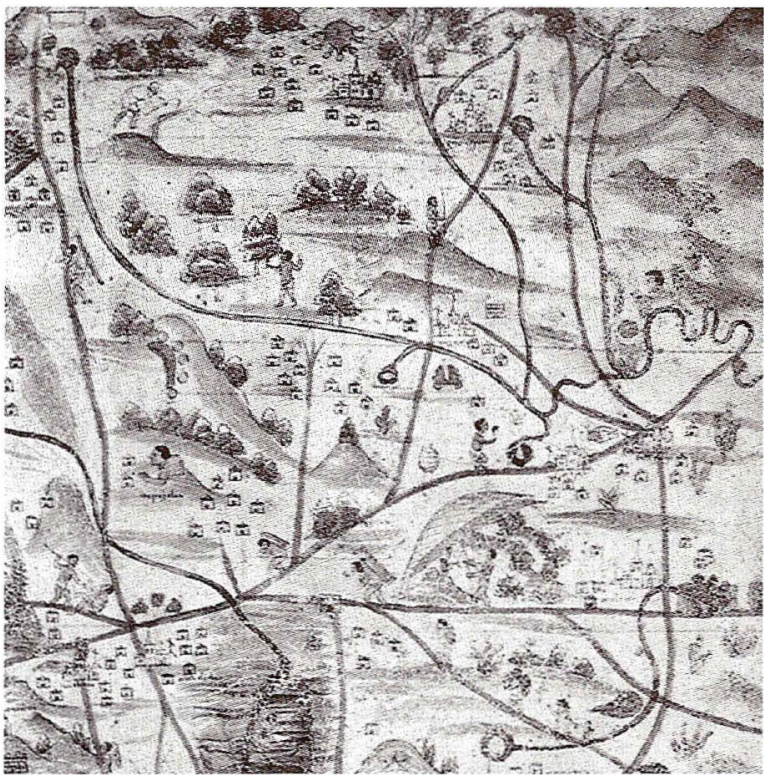

Alonso de Santa Cruz blev født i begyndelsen af r500-tallet. Godt tyve år gammel deltog han som bogholder i Sebastian Cabots ekspedition til Amerika, dog ikke til Mexico, men til Rio de la Plata. På denne rejse, som varede fra I526 til I530, lærte Santa Cruz sig at navigere og fremstille kort. Efter sin hjemkomst blev han ansat ved Casa de Contratacíon de las Indias i Sevilla, den myndighed som tilvirkede kort og søkort til Spaniens ekspeditioner og handelsflåder. Den 7. juli 1536 udnævntes Santa Cruz til archicosmographus, kejserlig hofkosmograf.

I 1530'erne foretog Casa de Contratacion en fuldstændig revision af padrón real. Padrón real var det hovedkort, hvorpå man indførte alle de observationer, som søfarende gjorde på deres rejser. Hver eneste spansk flåde, som anløb Sevilla, leverede skitser, kystbeskrivelser, klimatologiske og topologiske data, samt oplysninger om hvilke naturrigdomme, navigationsvanskeligheder og skabninger man kunne vente at møde på den anden side af havet. Med hver ny rejse kunne informationerne verificeres eller korrigeres, og sådan blev beskrivelsen hele tiden mere detaljeret og pålidelig.

Det arbejde som Santa Cruz ledede, at sammenstille en ny padrón real, indebar i praksis kortlægningen af hele verden, for det spanske imperium strakte sig jo til verdens yderste grænser. Karl V pålagde også Santa Cruz at skrive en redegørelse over alle verdens øer. Resultatet, Isolario general de todas las islas del mundo, blev fundet på Alonso de la Cruz' kontor efter hans død i 1567. Blandt efterladenskaberne fandt man også det Mexico-kort som findes i Uppsala, samt et verdenskort som også findes i Sverige, på Det Kongelige Bibliotek i Stockholm. Heller ikke i dette tilfælde ved man, hvordan kortet er havnet dér.

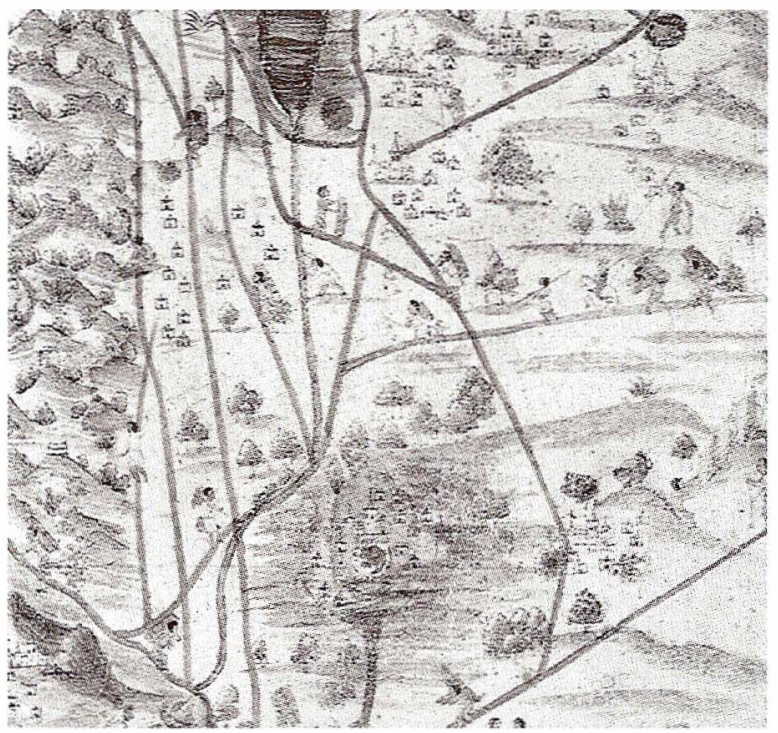

Ferdinand og Isabella, kongeparret som financierede Columbus' opdagelsesrejser, rejste på kryds og tværs gennem deres rige for at dømme, opkræve skatter, bese deres besiddelser og uddele privilegier til fortjenstfulde undersåtter. På samme måde regerede Sveriges regenter ved at føre 'Eriksgator' gennem riget. Hvor end monarken befandt sig, udgjorde hans krop landets centrum. Det territorium som blev be- 
trådt af hans fødder eller faldt under hans blik var hans ejendom. De mennesker som så herskerens krop var hans undersåtter.

Ferdinand og Isabella kunne regere ved at se og blive set. Derfor havde de intet større behov for kort. Men de regerede et lilliput-rige i sammenligning med det imperium, som deres arvtagere byggede. Karl V og Filip II havde måttet tilbringe måneder til søs og til fods, hvis de havde villet besøge deres territoriums yderste egne. Eftersom de ikke kunne overskue deres rige med egne øjne, måtte de skaffe sig stedfortrædende øjne. Som andre betydelige renæssancefyrster havde de kosmografer, som forevigede deres territoriale krav på smukke og værdifulde kort. Disse kort var magtsymboler. Besiddelse af et kort var tegnet på besiddelse af det territorium kortet forestillede, og gjaldt ofte som en slags tinglysning.

Renæssancens kort havde altså både en repræsenterende og en stedfortrædende funktion. De gav kejseren et billede af det imperium, han ikke selv kunne overskue. De gav ham også en bekræftelse på, at imperiet stod under hans herredømme. Fra alle provinser i imperiet strømmede kort til kejseren. Fra kejseren udspredtes til gengæld en anden slags billeder til alle afkroge af imperiet, nemlig portrættet af kejseren selv.

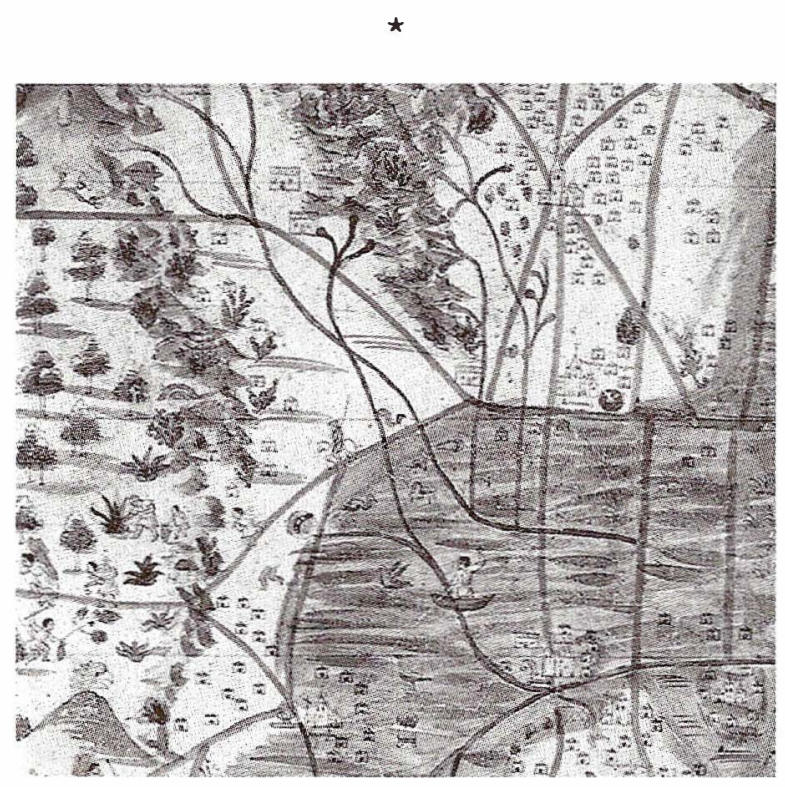

Kejseren inspicerede sin padrón real og bladede i sit atlas. Med hver ny flåde som vendte tilbage fra havet voksede hans land. Som kejserlig kosmograf påhvilede det Alonso de Santa Cruz at fortælle kejseren, hvordan dette ekspanderende imperium så ud. Hvor vanskelig opgaven var fremgår, hvis vi sammenligner hans virke med en af hans samtidige kollegers, André Thevet, hofkosmograf i Frankrig. Kosmografen, verdensbeskriveren, havde arvet et verdensbillede fra antikken og middelalderen, kodificeret frem for alt af Ptolomæus, og på det skulle han nu indtegne de fremmede kyster og mærkværdigheder, som de opdagelsesrejsende havde fundet hinsides havet.

I I500-tallet kendte man ikke jordens størrelse eller de nøjagtige grænser mellem hav og land. Man vidste heller ikke hvordan man beregnede et steds beliggenhed på kloden. Hvordan skulle kosmografen skabe orden i alle de søfarendes observationer? Thevet løste problemet ved at bruge det gamle verdensbillede som en ramme, han kunne udvide omtrent som det passede ham, når han skulle placere de øer og kyster som kaptajnerne aflagde rapport om. Men for at være tro mod sin tids viden indtegnede han også alle steder, som var dokumenteret i ældre rejseberetninger. Tidens vidensparadigme dikterede desuden, at han skulle angive områder og skabninger som burde eksistere ud fra skabelsens symmetri. Sådan gik det til, at verdens uudforskede periferi altid blev befolket af monstre og vidundere, såkaldte merveilles, som skimtedes i det fjerne på en grænse mellem myte og sandhed. I Thevets kosmografi kunne man finde England på samme kort som Atlantis og Kæmpernes Ø.

Da Europas tidlige kartografer skulle kortlægge den ny verden, skete det således ud fra renæssancekosmografiens modstridende principper. Thevet baserede sig på den ene side på de søfarendes udifferentierede rapporter og iagttagelser af verdens enkeltheder. På den anden side var han bundet af den ptolomæiske tradition og ville omfatte verdensaltet med et altseende guddommeligt blik. På den ene side måtte han sætte sin lid til øjets og instrumentets empiri, men på den anden side var sådanne observationer meningsløse, og kunne ganske enkelt 
ikke tolkes, så længe de ikke var indordnet i de gamle Imagines mundi. Men efterhånden som iagttagelser og opmålninger voksede $i$ antal sprængtes det gamle verdensbillede, og på højdepunktet af sin løbebane fandt Thevet sig derfor udstyret med empiriske observationer af hidtil ukendte områder, som gendrev alle kendte verdensbilleder. Problemet var, at der ikke fandtes noget nyt verdensbillede som kunne skabe sammenhæng mellem de nye områder. En midlertidig løsning på problemet tilbød netop Isolarion, som man kan sammenligne med et verdensatlas hvor selve verdenskortet mangler. Hvert område eller ø beskrives detaljeret på særskilte opslag, men der findes ikke noget oversigtskort som viser helheden, hvordan øerne eller områderne forholder sig til hinanden på jordens overflade.

Da det lykkedes kartograferne at udfærdige sådanne oversigtskort havde renæssancens kosmografi udspillet sin rolle. Den gamle tids kosmologiske fremstillinger af menneskets hjemsted i verdensaltet blev erstattet af kvadreringer i bredde- og længdegrader, som tillod geografen at stedfæste alle områder $\mathrm{i}$ deres rette position på jordens overflade. Blandt de første som udarbejdede dette system var netop Alonso de Santa Cruz. Til forskel fra André Thevet, kosmograf $\mathrm{i}$ et rige uden flåde eller egentlige kolonier, havde Alonso de Santa Cruz mulighed for at afprøve sine teorier empirisk. Han udsendte forespørgsler og indhentede observationer af solhøjde, måneformørkelser og andre astronomiske begivenheder. Ved hjælp af de opmålninger som strømmede ind kunne han placere alle byer og steder på deres rette plads i forhold til klodens længdeog breddegrader. Sådan indordnedes kejserens imperium i videnskabens modeller.

Længe var spørgsmålet om Sachalin en tvist blandt Europas geografer. Visse kort indtegnede Sachalin som en $\varnothing$, andre som en halvø. Videnskabsteoretikeren Bruno Latour beskriver, hvordan det lykkedes franskmanden Lapérouse at løse gåden den 17. juli I787. Lapérouses fartøj var forsynet med datidens mest avancerede, tekniske udstyr, omtrent som vore dages rumstationer. Hans ekspedition var udsendt for at indsamle oplysninger om Stillehavet $i$ alle dets aspekter. På Sachalin traf Lapérouse nogle indfødte som forstod, hvad han ville vide. De fortalte, at Sachalin er en ø. En af dem tegnede også et kort over øen i sandet. Da tidevandet steg og truede med at slette den betydningsfulde oplysning, tegnede en ung kineser kortskitsen i Lapérouses optegnelsesbog og angav til og med længdeskalaen ved streger, som angav antal dagsrejser i kano. Lapérouse planlagde at sejle ind $i$ kanalen næste dag for at kontrollere oplysningerne. Men da morgenen kom, lå tågen tæe og vindene var ugunstige. Lapérouse var tvunget til at sejle videre med uforrettet sag. Han havde dog i hvert tilfælde kortskitsen i sit optegnelseshæfte, og inden han forlod fastlandet sendte han optegnelsen sammen med positionsangivelser og tusinder af andre præparater til Frankrig med en person ved navn De Lesseps. Denne rejste tværs over Sibirien, Rusland og Europa og nåede endelig Versailles. $\mathrm{Nu}$ kunne Europas kartografer langt om længe indtegne Sachalins sande landform på deres kort.

Men hvem var egentlig $i$ besiddelse af sand viden om Sachalin? spørger Latour. De som var i besiddelse af sand viden om Sachalin, var de kinesiske fiskere, svarer han overraskende. Geograferne i Versailles som sammenstillede Lapérouses observationer havde alligevel ingen sand viden, for lige så lidt som Lapérouse selv havde de haft mulighed for at bekræfte den unge kinesers beskrivelse. Derimod fik de sømænd sand viden, som med det engelske skib Neptuna ti år senere lagde til ved Sachalin og kunne verificere Lapérouses oplysninger. Og disse sømænd kunne derefter bringe bekræftelsen tilbage til den europæiske videnskabs sæde.

Først anden gang vi står over for et fænomen har vi viden om det, forklarer Latour. At sømændene på Neptuna fik viden om Sachalin skyldtes, at de allerede havde set øen inden de kom til den, nemlig på de kort som blev fremstillet ved hjælp af Lapérouses observationer. Disse sømænd skulle senere bringe nye oplysninger tilbage til Europa, hvilket skulle 
hjælpe næste ekspedition til at hente yderligere oplysninger.

Videnskaben kan med andre ord defineres som evnen til at akkumulere oplysninger eller ting fra andre steder på et bestemt sted, og målet med denne akkumulation er derefter at gøre det muligt for andre mennesker fra samme sted at rejse ud og hente nye sager hjem. Det sted, hvor viden akkumuleres kan defineres som verdens centrum, mens de andre steder der plyndres for såvel information som for meget andet bliver verdens periferi.

Vor definition af videnskab er utænkelig uden sådan et netværk, hvor der findes et centrum og en periferi. Oplysninger og fænomener akkumuleres gradvis i centrum, noget som siden gør det nemmere for centrum at akkumulere endnu mere. Det som akkumuleres i centrum kaldes viden; men det er samtidig magt, kapital og profit. Selvom ingen af disse ord egentlig er dækkende for processen, mener Latour. Det vigtige er ikke hvad der akkumuleres, men at der akkumuleres. Hovedsagen er, at ét sted udøver fjernkontrol over andre steder, at man fra ét sted kan påvirke ukendte hændelser, mennesker og steder. Det gøres ved at flytte hændelserne, menneskene og stederne til en slags indsamlingssted, hvilket forudsætter at man gør dem mobile, så de kan indsamles, uforanderlige, så de ikke forandres eller ødelægges under flytning, samt kombinérbare, så de kan sættes sammen, sammenlignes og manipuleres af videnskabsmanden i verdens centrum.

$\star$

Santa Cruz' kort skulle i så fald vidne om alle de videnskabelige, politiske og materielle procedurer, som kræves for at afbilde og stedsbestemme Tenochtitlán og siden flytte stedet til centrum. Kortet viser også, at meningen med disse operationer er at befæste kejserens kontrol over det sted, som kortet repræsenterer. I så fald siger kortet, at verden har et centrum og en periferi, at centrum kendetegnes af at det akkumulerer viden om periferien, og at centrum gør fordring på at repræsentere periferien med videnskabelig præcision.
Således deltog Santa Cruz i en epistemologisk kolonisering, som rettede sig mod at indlemme det ukendte i det kendte; og selvom det ikke skete uden utallige tvistigheder mellem Europas lærde blev resultatet $\mathrm{i}$ alle tilfælde, at det ukendte til sidst forvandledes til noget kendt, det vil sige til noget hvis essens kunne gengives i videnskabens begreber.

Således viser også episoden med Lapérouse og kineseren, som tegnede sit kort i sandet, hvordan de indfødtes implicitte geografi gøres explicit af de europæiske geografer, hvordan de vildes lokale viden bliver til kartografernes universelle viden, hvordan de lokale indbyggeres omtrentlige antagelse forvandles til sikker videnskab når den bearbejdes i verdens centrum.

I det mindste forholder det sig sådan, sålænge vi betjener os af en representationel epistemologi, et videnssyn som søger den rette overensstemmelse mellem navn og virkelighed, mellem tegn og referent. I den ånd har Santa Cruz, Lapérouse og mange andre intellektuelle betragtet viden som resultatet af en identifikation af periferien gennem begreber, der er defineret $i$ verdens centrum.

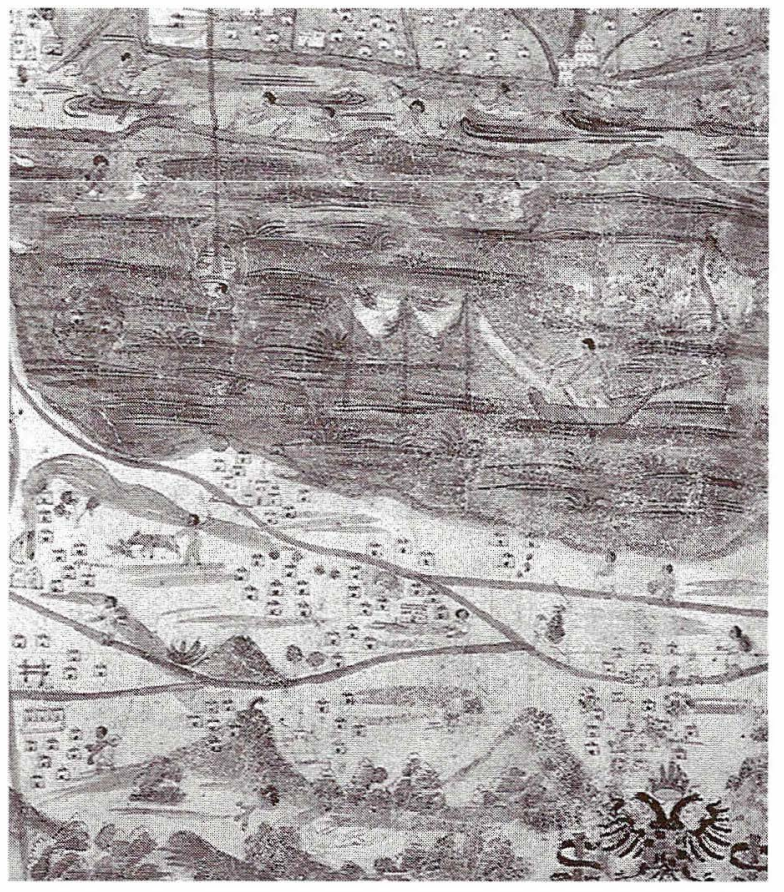


At Mexico-kortet havnede i Uppsala viser, at Uppsala er en del af verdens centrum, et sted som akkumulerer viden om andre steder i verden. Der findes forskellige teorier om, hvordan Santa Cruz' kort havnede i Uppsala. Ifølge et rygte skal den svenske hofmand Sparvenfeldt have købt det under sit ophold i Spanien ved slutningen af I60o-tallet. Betegnende nok skete indkøbet under stormagtstiden, da Sverige gik med planer om at blive centrum for den rette tro i Europa. Siden gik kortet over i glemslen og blev genopdaget i slutningen af I80o-tallet. Betegnende nok skete dette da den svenske søfarer og opdagelsesrejsende Nordenskiöld kastede sit blik på kortet under et besøg på biblioteket. Nordenskiöld var blandt dem, der i imperialismens storhedstid gav sig af med at kortlægge jordens sidste hvide pletter. Så snart han fik øje på Mexico-kortet indså han dets værdi for Sverige.

Ganske vist var Santa Cruz' kort på det tidspunkt tømt for al instrumentel erkendelsesværdi - det fandtes jo allerede langt mere moderne kort over Mexico City. Men til gengæld kunne kortet blive et symbol på den geopolitiske fordeling af viden: at Sverige skaffede sig kortet skyldtes ikke at landet havde interesser i Tenochtitlán, men at landet behøvede steder $\mathrm{i}$ periferien, $\mathrm{i}$ forhold til hvilke det kunne forankre sig selv i verdens centrum og derved befæste en geopolitisk overlegenhed. Dermed var Alonso de Santa Cruz' kort tømt for kognitivt indhold og blevet forvandlet til et rent sejrstrofæ, et bytte.

Der findes også en anden teori som stammer fra en vis biskop Nordin. I slutningen af I 700-tallet skal han for to franskmænd, som besøgte Uppsala, have afsløret, at kortet er kommet fra Prag, hvorfra grev Königsmarck havde stjålet det under den svenske plyndring i juli I648. Måske fragtedes det endda hertil i samme røverkiste som Sølvbiblen.

I alle tilfælde sidder Mexico-kortet i dag på væggen i Carolina Rediviva, biblioteket i Uppsala. Jeg har ofte grundet over kortet og prøvet at forstille mig, hvilken sensation det må have været, da Alonso de
Santa Cruz overrakte det til den spanske kejser - et detaljeret kort over den største og fornemste by, ikke blot i Ny Spanien, men i hele hans vældige koloniverden, juvelen $\mathrm{i}$ imperiets krone. I næste øjeblik gribes jeg af svimmelhed, for det går også op for mig, at havde kejseren nu spurgt Santa Cruz om betydningen af det ene eller det andet af kortets tegn, om højden på de angivne bjergtoppe eller om befolkningstallet i Tenochtitlán, da havde kosmografen måttet rømme sig og svare: „Eders Højhed, det ved jeg ikke noget om,“

Alonso de Santa Cruz, kortets påståede ophavsmand, satte aldrig sin fod i Mexico.

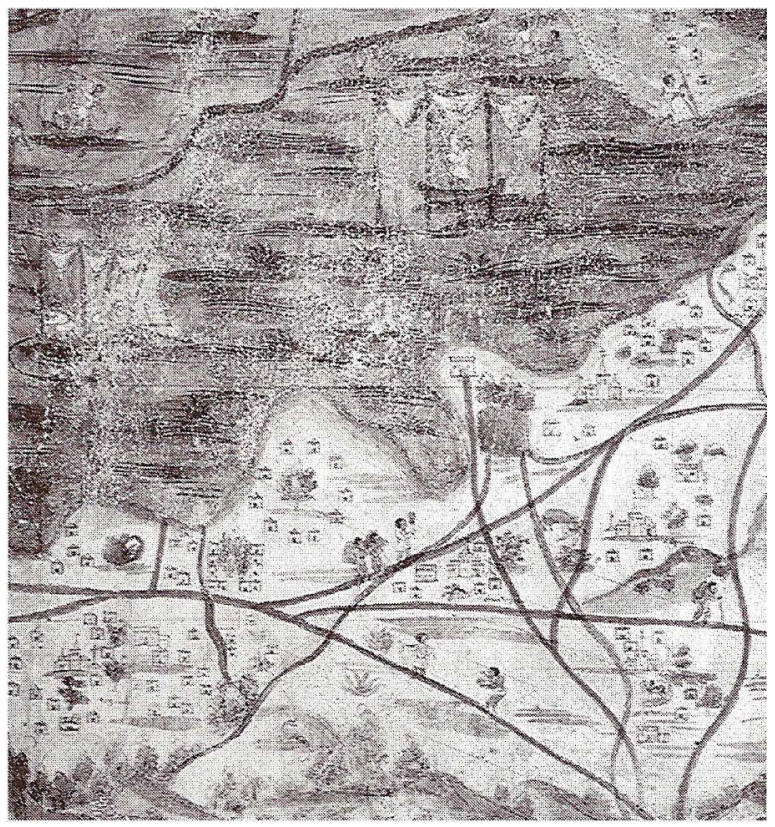

Alonso de Santa Cruz tegnede ganske vist selv et kort over Tenochtitlán og også det er bevaret, for det indgår i hans Isolario general de todas las islas del mundo. Men det er let at vise, at dette kort er kopieret efter det som hænger i Uppsala. Da Santa Cruz kopierede stedsnavnene fra originalkortet til sit eget atlas stavede han uheldigvis forkert. På originalkortet er navnene korrekt stavet. Den spanske kosmograf viste åbenbart ikke, hvordan man bogstaverede de vigtigste bydele i Ny Spaniens hovedstad. Men 
selvom forskerne for længe siden har indset, at Alonso de Santa Cruz umulig kan være kortets ophavsmand udpeger man ham fortsat som dets ophavsmand.

Vi ved ikke, hvem der tegnede Mexico-kortet. Men man behøver ikke at vide meget om nahuatlkulturen for at kunne se, at det er tegnet af en indfødt aztek. To forhold taler herfor. For det første mængden af hieroglyfiske tegn som angiver stedsnavnene på nahuatl; mange spanske præster lærte sig ganske vist at læse aztekernes tegnsprog, men historien giver intet eksempel på at nogen skrev det. Det andet forhold som viser at kortet er tegnet af en indianer er, at det har et tydelig socialt og historisk indhold, som formidles af alle menneskefigurernes gøremål og indbyrdes relationer. Her ser man forskellen mellem europæisk og mexikansk kartografi; når folkene i det prækolumbianske Amerika kortlagde et sted afbildede de egentlig et socialt og politisk fællesskab. Den europæiske kartografi rendyrkede på samme tid topografien, korografien og geografien, det vil sige en korrekt projektion og krympning af stedets fysiske og materielle udseende. Men selvom det er let at se, at dette kort er udformet af en indfødt, fremgår det lige så tydeligt at denne var dybt påvirket af europæiske modeller. Afbildningen af huse og gader er af sammen slags som forekommer på Santa Cruz' egne kort.

Heraf kan vi drage en hypotetisk slutning: kortet som tilskrives Santa Cruz, og som Santa Cruz selv kopierede og indlemmede $i$ et af sine hovedværker, er tegnet af en aztek fra landets kulturelite, der sandsynligvis gennemgik sin uddannelse $i$ en af de klosterskoler, som dominikanere og fransciskanere oprettede kort efter erobringen for at omvende indianernes sjæle fra afgudsdyrkelse til den sande tro. Den person som tegnede Mexico-kortet var halvt vendt mod sin egen tradition, halvt mod den viden som spanierne formidlede. I hans eller hendes liv blev Spaniens verdensbillede brudt mod den epistemologi, som dyrkedes af aztekerne i hundreder af år.

Derfor kunne hverken Santa Cruz eller kejseren forstå kortet. Hvordan de end vendte og drejede det forblev dele af det ubegribelige. Korttegneren lod to modsatrettede verdensbilleder krydse hinanden og billedet af Tenochtitlán forandres afhængig af, hvilket af de to perspektiver vi indtager. Når vi står foran kortet ser vi $i$ grunden to forskellige steder. Billedet af det aztekiske Tenochtitlán og billedet af det spanske México ligger i lag over hinanden som kortets forskellige lag af farve.

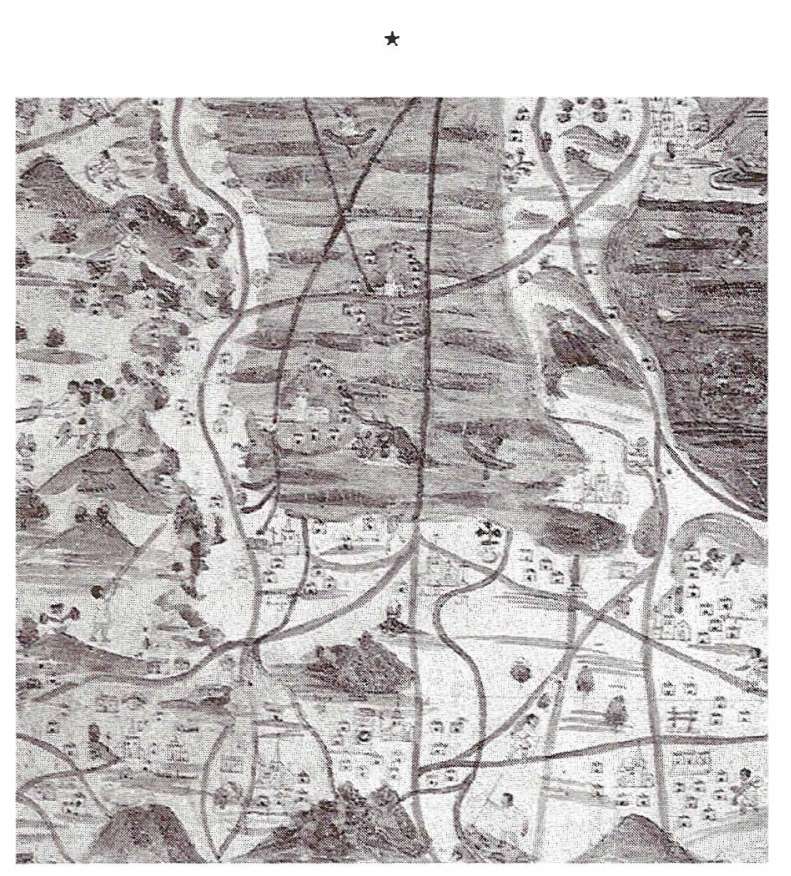

En følge af Europas søgen efter sandheden om planeten Jorden var at ikke-europæiske forestillinger om rummet blev undertrykt. Efter erobringen måtte aztekerne finde sig $\mathrm{i}$, at deres måde at ordne historien og rummet på blev udlagt som falsk, irrelevant eller $\mathrm{i}$ bedste fald som noget, der skulle rettes af spanske videnskabsmænd og præster. Aztekiske dokumenter og maya-dokumenterne blev kastet på bålet. Stedets sandhed, som blev udviklet af folkene selv på kontinentet, er én gang for alle bortrøvet. Derfor famler vi endnu den dag i dag efter dette sted med vore kejtede katakreser: „den ny verden“, ,indianer“, „Vestindien“, „Amerika“, navne som siger mere om Europas forventninger og fejltagelser end om stederne, de betegner.

En anden følge af Europas vidensekspansion var, at man spredte en slags læsekyndighed i europæisk 
kartografi også til ikke-europæere. På sin vis omprogrammeredes den rumlige anskuelse hos mennesker på begge sider af Atlanten.

Men i så fald bør vi tilbagevise den repræsentationelle epistemologi, som siger at viden forudsætter et centrum, som akkumulerer observationer og udformer begreber, som formår at gengive periferien stadig mere objektivt og i overensstemmelse med sandheden. I stedet burde vi forestille os epistemologi og vidensproduktion som noget performativt. En performativ epistemologi ville hævde, at de opdagelsesrejsendes beskrivelser af det nye og ukendte, deres vilje til at indlemme det $\mathrm{i}$ kundskabens arkiv, ikke drejer sig om at fremstille begreber som stemmer overens med en allerede eksisterende virkelighed. Hvad de opdagelsesrejsende gør er snarere at konstruere eller rent ud opfinde en $n y$ virkelighed, som ikke har noget at gøre med den virkelighed, som aztekerne og andre folk i „Amerika“ levede i. På samme måde opfandt den ukendte korttegner en ny virkelighed, da han eller hun satte skårene af sin sønderslåede verden sammen og afstedkom et af de første udtryk for den spansk-mexikanske kulturblanding.

Det ville altså være fejlagtigt at stille en universalistisk og protovidenskabelig virkelighedsopfattelse over for aztekernes lokale og partikulære verdensbillede. Tværtimod har vi at gøre med to vidensformer, der er lige lokale, med den forskel at den ene, den europæiske, har form af et netværk der retter sig mod at flytte oplysninger og ting fra et sted til et andet. Den 'sande' måde at repræsentere det ukendte og indlemme det $\mathrm{i}$ det kendte bestemmes ikke af nogen form for immanent epistemologisk overlegenhed, men som regel af den magt der står bag kartografens egne metoder og perspektiv. I det omfang en vidensform virker almengyldig beror det på, at den er indfældet i et større netværk af institutioner og praksiser, ikke på at den i sig selv er mere universel end andre vidensformer. Ud fra vidensinterne kriterier er det umuligt at afgøre om den ene måde at ordne verden på er sandere end den anden.

Beviset har I foran jer. Kortet er ikke tegnet af Santa Cruz, ikke af en europæisk kosmograf, geograf eller videnskabsmand, men af et dannet men- neske fra et slagent folk. Eftersom det er tegnet af en indianer burde det klassificeres som udtryk for en lokal vidensform, men at det er forsynet med såvel Santa Cruz' signatur som kejserens våben viser at det klassificeredes som en handling, der blev udført det sted hvor man akkumulerer sikker viden, i verdens centrum. I dette tilfælde har magtens og forskningens netværk altså autoriseret det lokale og perifere som en påstået almengyldig dokumentation af Tenochtitlán, endda i en grad så Santa Cruz ikke tøvede med at indføje en dårlig kopi af kortet $\mathrm{i}$ den Isolario general som han sammenstillede til kejseren. Således får kortet en dobbelt oprindelse og en dobbelt identitet. Eftersom det på en gang tilhører både periferien og centrum, både Mexico og Europa, både det partikulære og det universelle, formår det at dekonstruere modsætningen: mellem centrum og periferi er der ikke længere nogen forskel; de to modpoler går i ét. I dette punkt, midt $\mathrm{i}$ den forvirrende strøm af epistemologiske, symbolske, politiske og militære transaktioner befinder kortet sig altså. Det viser således at viden ikke produceres $i$ et centrum som akkumulerer stadig mere forfinede og nøjagtige fremstillinger af periferien; ny viden oparbejdes snarere performativt ud fra et mellemrum som ophæver såvel centrum som periferi - et mellemrum hvor sandt og falsk, subjektivt og objektivt endnu ikke er adskilt.

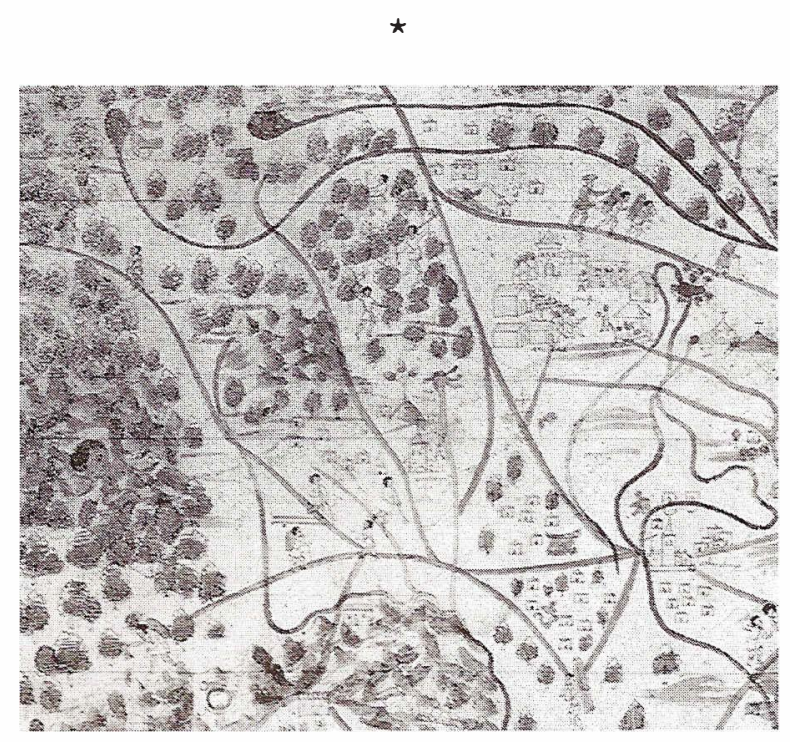


Hvad har dette at gøre med essayet? Svaret er at essayet, det kritiske essay, altid taler ud fra og søger tilbage til netop dette mellemrum. Det er i den ånd Adorno hævder at hos Walter Benjamin, et af århundredets bedste essayister, er hver mening lige langt fra centrum. I samme ånd skriver Massimo Caccari om Robert Musils essaykunst, at den hverken kredser omkring et centrum eller påberåber et fremtidigt videnssystem. „Essayet mistænkeliggør enhver forestilling om centrum, om orden, om uimodsigelige grundsætninger." Essayet taler i stedet ved en korsvej hvor modstridende begreber, fænomener og hændelser kolliderer med hinanden. Resultatet af disse kollisioner er ikke det vi kalder virkelighed, men det Robert Musil ville kalde mulighed.

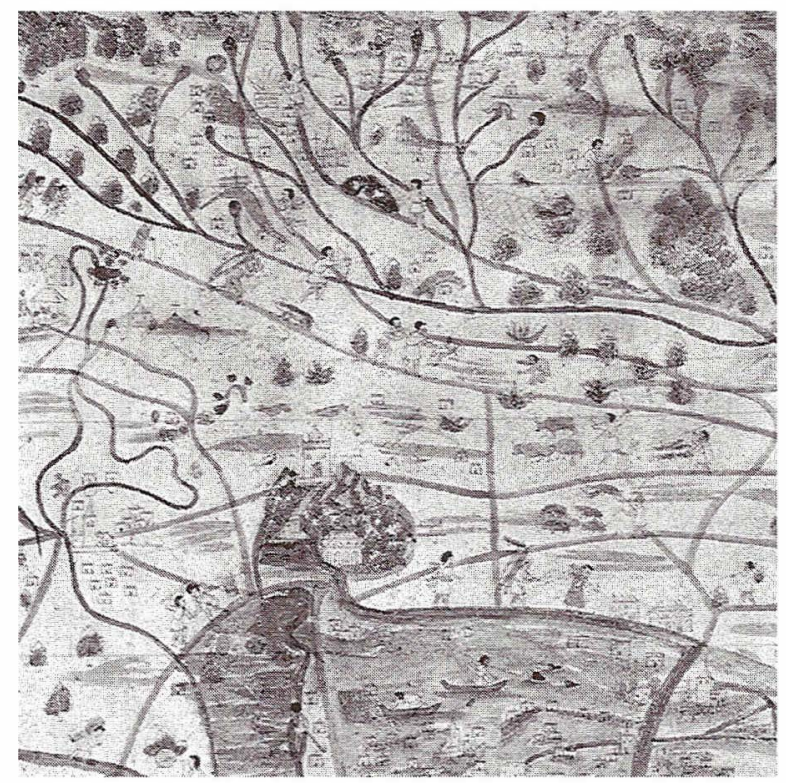

På kortet findes periferien endnu, midt $\mathrm{i}$ verdens centrum, maskeret, men alligevel synlig for den som vil se. Dermed bevarer det erindringen om en anden slags epistemologisk rationalitet, og det opretholder en idé om, at den imperialistiske organisering af geopolitikken ikke var den eneste mulighed, men at der findes andre måder at ordne verden på, lige som der i I500-tallet fandtes alternative måder at gengive Mexico-dalen på, allesammen lige tænkelige.

Det er derfor dette kort fremkalder angst og forvirring; det forestiller verden sådan som den viser sig hinsides den begrebslige kategorisering af verden som på en gang er nødvendig og fejlagtig, som er umulig af fornægte og lige så umulig at acceptere. Ud fra denne svimlende placering stiller den kulturkritiske essayistik et lige så umuligt som nødvendigt spørgsmål: hvordan kan man lære sig at tænke ud fra Montezumas perspektiv? Hvordan kan man rekonstruere verden ud fra aztekernes ruiner?

I De usynlige byer skildrer Italo Calvino en serie samtaler mellem Marco Polo og Kublai Kahn. Kejseren Kublai Kahn sidder hjemme i paladset og beder Marco Polo beskrive de forskellige steder i sit imperium. Marco Polo beretter om fjerne byer, som er bygget på grænsen mellem myte og sandhed. Kublai Kahn blader desorienteret i sit atlas. Det er som om han ikke kan tåle den mangfoldighed af livsformer og samfundstyper, som Marco Polo rapporterer. Han giver ordre til, at man overalt i hans imperium skal bygge en og samme endegyldige by, en by med mure af stål. På dette initiativ svarer Marco Polo at han vil „samle asken af andre, mulige byer som måtte jæunes med jorden for at give plads for kejserens by, byer som aldrig kan genopbygges eller huskes.“

$\star$

Det var et overjordisk øjeblik, skriver den franske forfatter Le Clézio om mødet mellem Cortés og Montezuma. „Det var et kulminationsøjeblik da to verdener mødtes, to civilisationer - den ene bygget på guddommelig magt, den anden bygget på guld og våbenmagt. Der er noget i dette møde som fremkalder en vildelse, for hele Vesterlandets fremtid afhang af hvordan det ville forløbe."

Den som har forsøgt at begribe mødet mellem Cortés og Montezuma har følt samme vildelse, fascination, angst, foruroligelse, svimlen og forvirring. Dette er den eneste gang i historien, hvor to mægtige kulturer, ubekendte med hinandens verdensbil- 


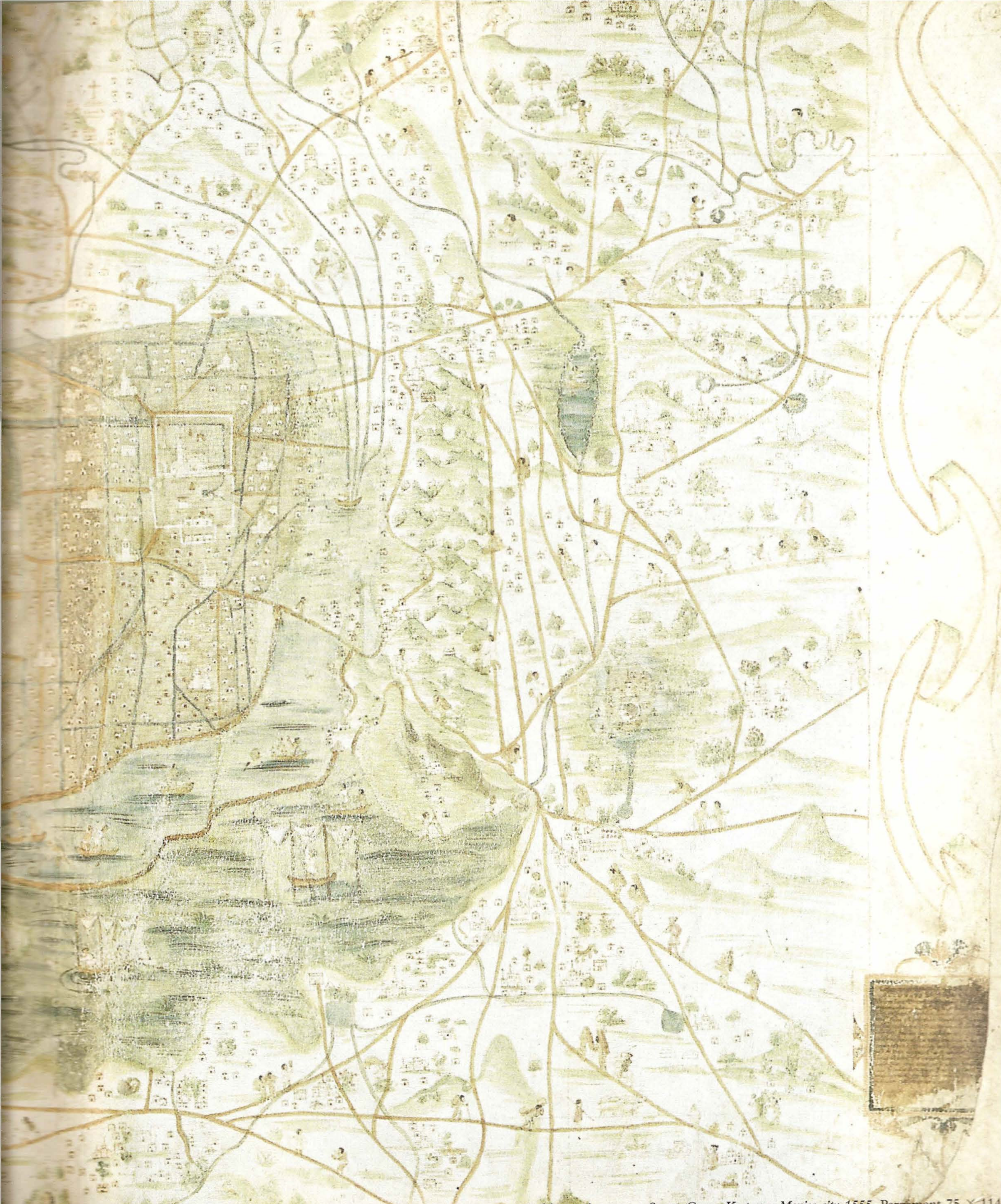

Fold-out: Alonso de SANTA CRUZ: Kort over Mexico city 1555. Pergament 75 X 114 


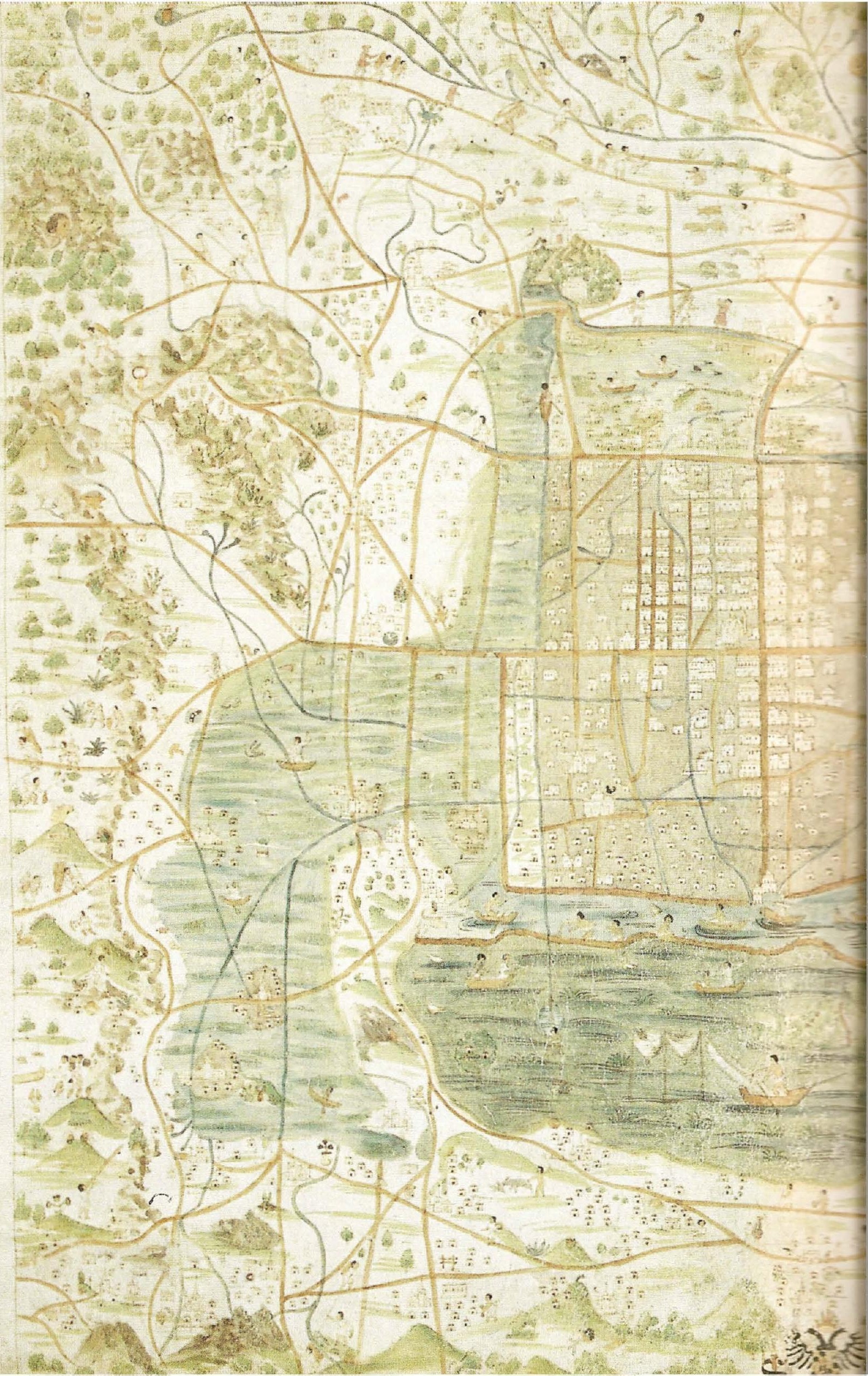


leder, står ansigt til ansigt. Aldrig var fremmede så fremmede som da.

Men fascinationen bliver snart til væmmelse. Da Cortés kommer til Mexico bor der 25 millioner mennesker i landet. År I600 er befolkningen reduceret til en million. I sit livs efterår, da Cortés og de andre conquistadorer var døde, så Bernal Díaz del Castillo endnu engang den strålende stad på vandet for sit indre blik:

Jeg så det hele og tænkte at man aldrig nogensinde igen skulle komme til at opdage lande som disse, for på den tid var der endnu ingen som kendte til Peru. I dag er alt som fandtes dér jevnet med jorden, tabt, uden en eneste overlevende.

Díaz skrev disse linier i I555. Da havde spaniererne for længe siden raseret Tenochtitlán, Cortés bygget sit palads og paven sin katedral. Tempelområdets ruiner var forvandlet til den store, åbne plads, Zócalo. Samtidig med at Díaz begyndte at skrive erobringens memoirer, begyndte en anden mand at tegne et kort over byen, som er et vidnesbyrd om hvordan den gamle by jævnes med jorden og hvordan en ny bygges på ruinerne. Dette kort er af ejendommelige veje havnet i Uppsales universitetsbibliotek. Dets ophavsmand siges at være Alonso de Santa Cruz.

På dansk ved Marianne Ping Huang

\section{Litteratur}

Adorno, Theodor W: „Der Essay als Form“, Noten zur Literatur. Frankfurt am Main: Suhrkamp, 1974, s. 9-33.

Brotton, Jerry: Trading Territories: Mapping the Early Modern World. London: Reaktion Books, 1997.

Cacciari, Massimo: Posthumous People: Vienna at the Turning Point. Overs. til engelsk af Rodger Friedman. Stanford: Stanford University Press, 1996.

Calvino, Italo: Invisible Cities. Overs. til engelsk af William Weaver. New York: Harcourt, Brace and Jovanovich, 1974.

Cortés, Hernando: Five Letters 1519-1526. Overs. till engelska av J. Bayard Morris. New York \& London: Norton, 1969.
Díaz del Castillo, Bernal: The Discovery and Conquest of Mexico 1517-1521. Overs. til engelsk af A. P. Maudslay. New York: Da Capo Press, 1996.

Latour, Bruno: Science in Action: How to Follow Scientists and Engineers through Society. Cambridge: Harvard University Press, 1987.

Le Clézio, Jean-Marie Gustave: Le rêve mexicain ou la pensée interrompue. Paris: Gallimard, 1988.

Lestringant, Frank: L'Atélier du cosmographe. Paris: Albin Michel, I991.

León Portilla, Miguel, og Carmen Aguilera: Mapa de Mexico Tenochtitlan y sus contornos hacia 1550. Mexico City: Celanese Mexicana, I986.

Mignolo, Walter: The Darker Side of the Renaissance: Literacy, Territoriality and Colonization. Ann Arbor: The University of Michigan Press, I995.

Mundy, Barbara E: The Mapping of New Spain: Indigenous Cartography and the Maps of the Relaciones Geográficas. Chicago: The University of Chicago Press, 1996.

O’Gorman, Edmundo: La Invención de Ameérica. Investigación acerca de la estructura histórica del nuevo mundo y del sentido de su devenir. Mexico: Fondo de Cultura Económica, I958, nyt opl. I995.

Todorov, Tzvetan: La Conquête de l'Amérique. Paris: Seuil, 1982 .

Toussaint, Manuel, Federico Gomez de Orozco og Justino Fernandez: Planos de la ciudad de Mexico. Siglos XVI $y$ XVII. Estudio historico, urbanistico y bibliografico. Universidad Nacional Autonoma de Mexico: Instituto investigaciones esteticas, 1938, nyt opl. I990.

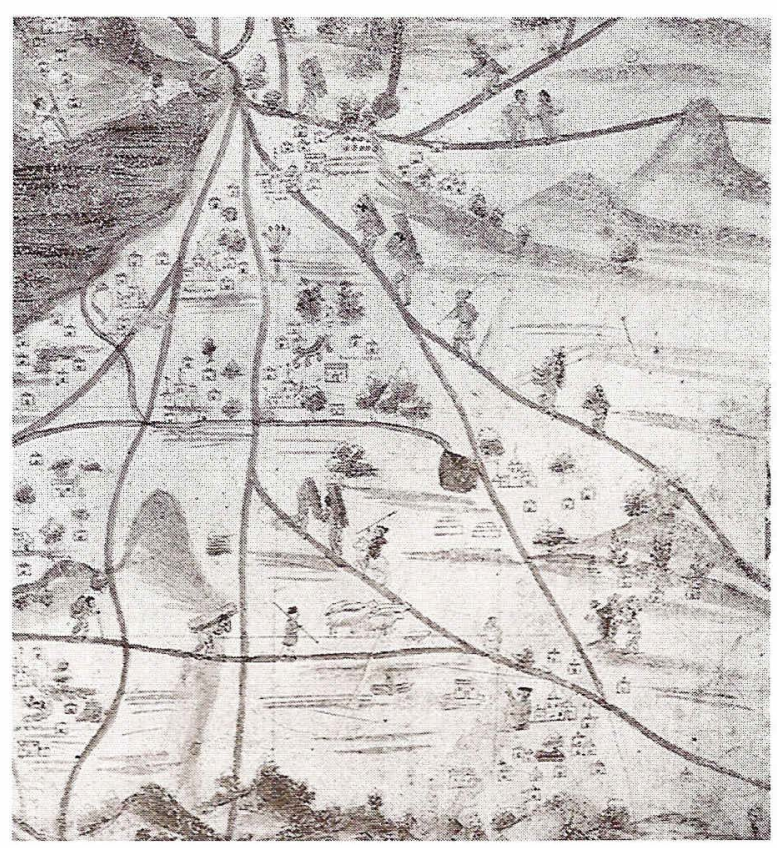

